\title{
Molecular Identification and Traceability of Illegal Trading in Lignobrycon myersi (Teleostei: Characiformes), a Threatened Brazilian Fish Species, Using DNA Barcode
}

\author{
Alexandre dos Santos Rodrigues, ${ }^{1}$ José Henrique Souza Galdino Brandão, ${ }^{1}$ \\ Jamille de Araújo Bitencourt, ${ }^{1}$ Ricardo Jucá-Chagas, ${ }^{1}$ Iracilda Sampaio, ${ }^{2}$ \\ Horácio Schneider, ${ }^{2}$ and Paulo Roberto Antunes de Mello Affonso ${ }^{1}$ \\ ${ }^{1}$ Department of Biological Sciences, Universidade Estadual do Sudoeste da Bahia, Rua José Moreira Sobrinho, $s / n$, \\ Bairro Jequiezinho, 45206-190 Jequié, BA, Brazil \\ ${ }^{2}$ Institute of Coastal Studies (IECOS), Universidade Federal do Pará, Alameda Leandro Ribeiro s/n, Bairro Aldeia, \\ 68600-000 Bragança, PA, Brazil
}

Correspondence should be addressed to Paulo Roberto Antunes de Mello Affonso; paulomelloaffonso@yahoo.com.br

Received 29 June 2016; Revised 16 August 2016; Accepted 17 August 2016

Academic Editor: Jaewoo Yoon

Copyright (c) 2016 Alexandre dos Santos Rodrigues et al. This is an open access article distributed under the Creative Commons Attribution License, which permits unrestricted use, distribution, and reproduction in any medium, provided the original work is properly cited.

\begin{abstract}
Lignobrycon myersi is a threatened freshwater fish species and endemic of a few coastal rivers in northeastern Brazil. Even though the Brazilian laws prohibit the fisheries of threatened species, L. myersi is occasionally found in street markets, being highly appreciated by local population. In order to provide a reliable DNA barcode dataset for L. myersi, we compared mitochondrial sequences of cytochrome c oxidase subunit I (COI) from fresh, frozen, and salt-preserved specimens. Phylogenetically related species (Triportheus spp.) and other fish species (Astyanax fasciatus) commonly mixed with L. myersi in street markets were also included to test the efficiency of molecular identification. In spite of the differences in conservation processes and advanced deterioration of some commercial samples, high-quality COI sequences were obtained and effective in discriminating $L$. myersi specimens. In addition, while populations from Contas and Almada River basins seem to comprise a single evolutionary lineage, the specimens from Cachoeira River were genetically differentiated, indicating population structuring. Therefore, DNA barcoding has proved to be useful to trace the illegal trading of L. myersi and to manage threatened populations, which should focus on conservation of distinct genetic stocks and mitigation on human impacts along their range.
\end{abstract}

\section{Introduction}

The hydrographic coastal basins in Eastern Brazil are characterized by high endemism of aquatic species [1] with an alarming number of critical areas (about $46 \%$ of the total region) for conservation of fish species [2]. These areas combine endemic species, advanced deforestation, overexploitation, and introduction of invasive species, being particularly predominant in drainage of northeastern Brazil $[2,3]$. The species Lignobrycon myersi Miranda Ribeiro, 1956, perfectly exemplifies this situation. This small fish species (up to $11 \mathrm{~cm}$ in total length) is endemic of southern Bahia in northeastern Brazil, formerly described only from a single stream from Almada River basin [4]. About two decades later, this species was found in Contas River basin close to Jequié, one of the largest cities in southern Bahia [3], and a few specimens have been recently collected in Cachoeira River basin [1]. Because of their restricted range (about $200 \mathrm{~km}$ ) and habitat modifications (Contas and Cachoeira Rivers are highly polluted while invasive carnivore fishes have been introduced in the three basins), L. myersi was included in Red List of Threatened Species of Brazilian Fauna $[3,5]$.

The fisheries and trading of threatened species are illegal according the Brazilian laws [6], but monitoring of fish products is largely ineffective in street markets in several regions of Brazil [7]. Therefore, specimens of L. myersi have 




(a)

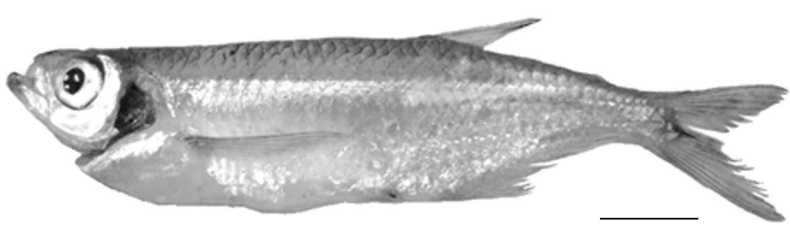

(b)

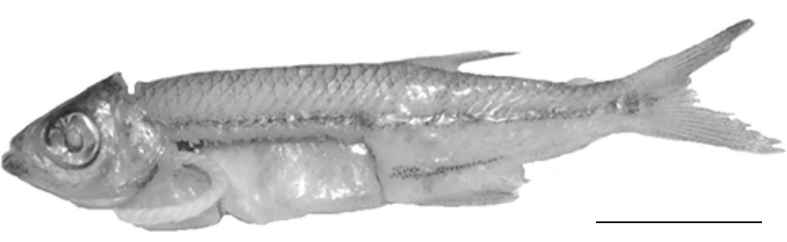

(c)



(d)

FIgure 1: Map of the state of Bahia in northeastern Brazil (a), indicating the three collection sites (1: Contas River, 2: Almada River, and 3: Cachoeira River) of Lignobrycon myersi. On the right, photographs of fresh (b), frozen (c), and salt-conserved (d) specimens of $L$. myersi (the bar equals $1 \mathrm{~cm}$ ).

been traditionally collected and commercialized with other morphologically similar and small characins (e.g., species of Triportheus and Astyanax) in street markets of southern Bahia, northeastern Brazil (pers. obs.). After being eviscerated, the whole specimens are fried and served as a local and highly appreciated appetizer, called "pititinga." This practice hinders the precise identification of fish products based on external morphology thus favoring the commercialization of threatened species in markets across the region.

In this sense, forensic genetics represents a reliable approach to minimize the frauds in fish products from endangered species related to nondeclared or mislabeled fisheries [8]. Besides being useful for identifying wildlife, DNA analysis is also able to discriminate local fish stocks and overexploitation of specific populations [9-11]. Over the last years, subunit I of the cytochrome $\mathrm{c}$ oxidase (COI) has been successfully applied to establish interspecific molecular divergence inasmuch as they provide a species-specific DNA barcode [12-15].

In the present paper, $\mathrm{COI}$ sequences were analyzed to identify specimens of Lignobrycon myersi throughout their range and commercialized in street markets of southern Bahia, representing the largest DNA sample obtained for this species so far. In order to evaluate whether the quality of muscular tissue could interfere in the reliability of molecular data or not, frozen and salt-preserved market samples were compared to the tissue of fresh and recently collected specimens. In addition, the same DNA regions were sequenced from other phylogenetically related species and other characins commonly commercialized with L. myersi to test the utility of COI as DNA barcodes.

\section{Materials and Methods}

2.1. Sampling. A total of 41 samples of muscle tissue (nearly $0.5 \mathrm{~cm}^{3}$ ) of L. myersi from Pedra reservoir in Contas River, Jequié, Bahia, were obtained from local fishermen at street markets. These samples have been frozen for undetermined periods or else covered with salt and exposed to room temperature (about 20 to $35^{\circ} \mathrm{C}$ ) along with other small fish species (Figure 1). For comparative analyses, tissue samples of recently collected specimens of $L$. myersi from the typelocality in Almada River basin $(n=14)$ and Cachoeira River basin $(n=4)$, Ilhéus, Bahia, were included in the molecular analyses, thus representing the total range of this species (Figure 1). Voucher specimens were deposited in the fish collection of Instituto Nacional da Mata Atlântica (INMA) in Santa Teresa, State of Espírito Santo (\#MBML6400). Because of their close phylogenetic relationship with Lignobrycon [16, 17], COI sequences of Triportheus species obtained in the present study and available in GenBank were included. These additional sequences comprised Triportheus guentheri 
from São Francisco River (present paper; HM404957.1) [18], T. nematurus (GU701461.1; GU701945.1; GU701458.1; GU701457.1) [19], and T. angulatus (GU060427.1) [20]. Moreover, specimens of Astyanax fasciatus from Contas River basin, usually found mixed with L. myersi individuals in markets under the denomination of "piabas," were also analyzed.

\subsection{Amplification and Sequencing of COI Fragments. Total} DNA was extracted from muscle tissue using the kit Wiz$\operatorname{ard}^{\circledR}$ Genomic DNA Purification (Promega) according to manufacturer's instructions. The amount of integrity of extracted DNA was checked after electrophoresis in $0.8 \%$ agarose gel stained with GelRed ${ }^{\mathrm{TM}}$ and visualization under UV light. Even though the commercial samples presented highly degraded DNAs, we estimated a mean DNA concentration of $50 \mathrm{ng} / \mu \mathrm{L}$. The COI sequences were amplified via PCR using the primers: VFli_t1 $5^{\prime}$-TGTAAAACGACGGCCAGTTCTCAACCAACCACAAAGACATTGG-3' and VRli_t1 $5^{\prime}$-CAGGAAACAGCTATGACTAGACTTCTGGGTGGCCAAAGAATCA-3' [21].

The PCR conditions comprised a final concentration of $0.2 \mathrm{mM}$ dNTP, $1 \mathrm{x}$ buffer, $2 \mathrm{mM} \mathrm{MgCl}_{2}, 0.4 \mu \mathrm{M}$ of each primer, $1 \mathrm{U}$ of Taq DNA polymerase, $50 \mathrm{ng}$ of template DNA, and ultrapure water to a final volume of $15 \mu \mathrm{L}$. The amplification program encompassed a first denaturation step at $94^{\circ} \mathrm{C}$ for $5 \mathrm{~min}$, followed by 30 cycles at $94^{\circ} \mathrm{C}$ for $40 \mathrm{sec}, 55^{\circ} \mathrm{C}$ for $40 \mathrm{sec}$, $72^{\circ} \mathrm{C}$ for $30 \mathrm{sec}$, and final extension at $72^{\circ} \mathrm{C}$ for $7 \mathrm{~min}$.

The sequencing reaction was carried out with the kit Big Dye (ABI Prism ${ }^{\mathrm{TM}}$ Dye Terminator Cycle Sequencing Reading Reaction, Applied Biosystems) to a final volume of $10 \mu \mathrm{L}$, using $2.0 \mu \mathrm{L}$ of each primer $(0.8 \mathrm{pmol} / \mu \mathrm{L}), 1 \mu \mathrm{L}$ of PCR product, $1 \mu \mathrm{L}$ of Big Dye mix, $1.5 \mu \mathrm{L}$ of buffer, and $4.75 \mu \mathrm{L}$ of ultrapure water. Sequences were obtained in a Prism 3500XL ABI (Applied Biosystems) automatic sequencer.

2.3. Sequence Analyses. The sequences were edited in the software BioEdit Sequence Alignment Editor 7.1.9 [22] and aligned using ClustalW [23] also available in BioEdit. Afterwards, they were submitted to BLAST [24] to confirm and compare the sequenced regions with similar sequences available in GenBank (http://www.ncbi.nlm.nih.gov/).

The levels of intra- and interspecific diversity as well as the construction of trees using Neighbor-Joining (NJ) [25] according to Kimura-2-parameter (K2P) evolutionary model [26] were performed in the software MEGA v. 6 [27], as proposed in DNA barcoding. The branch support was established by bootstrap after 10,000 replications [28]. In addition, a COI tree based on Bayesian inference (BI) was built in the software MrBayes v. 3.1 [29], using the evolutionary model $\mathrm{HKY}+\mathrm{I}$, as determined by jModelTest [30]. In this case, the support of branches was estimated according to a posteriori probabilities.

The species delimitation was also estimated by barcode gap analysis using ABGD (Automatic Barcode Gap Discovery for primary species delimitation) in the platform http:// wwwabi.snv.jussieu.fr/public/abgd/ and the Bayesian implementation of the PTP (bPTP) available in http://species.hits .org/ptp/. The bPTP model [31] adds Bayesian support values
TABLE 1: Genetic distance of COI sequences among genera based on K2P model.

\begin{tabular}{lccc}
\hline Genus & Sample size $(n)$ & 1 & 2 \\
\hline (1) Lignobrycon & 59 & - & \\
(2) Triportheus & 9 & 0.178 & - \\
(3) Astyanax & 3 & 0.220 & 0.241 \\
\hline Mean & & 0.213 & \\
\hline
\end{tabular}



FIgURE 2: Consensus tree based on NJ and BI analysis of COI sequences in L. myersi from Contas $(n=41)$, Almada $(n=14)$, and Cachoeira $(n=4)$ River basins, Triportheus guentheri $(n=4), T$. angulatus $(n=1)$, T. nematurus $(n=4)$, and Astyanax fasciatus $(n=$ $3)$. * indicates the sequences obtained in GenBank. The columns on the right indicate the five taxonomic entities (species) recovered by ABGD and bPTP algorithms.

to the species identified from previous Maximum Likelihood obtained in MEGA v. 6 [27]. In this study, the bPTP settings were rooted trees, 100,000 Markov Chain Monte Carlo $($ MCMC) generations (thin $=100)$, and burn-in of $10 \%$.

Furthermore, a haplotype network based only on COI sequences of $L$. myersi was obtained using the software Haplotype Viewer [32] in order to evaluate putative differences among populations. The values of haplotype $(h)$ and nucleotide $(\pi)$ diversity were calculated with DNA Sequence Polymorphism, DnaSP v. 5.10 [33].

\section{Results and Discussion}

The COI dataset for $L$. myersi comprised 59 sequences (662 bp), besides those obtained from Astyanax fasciatus (Contas River basin) and three species of Triportheus, totaling 71 COI sequences. The genetic divergence among the three genera ranged from $17.8 \%$ to $24.1 \%$, with a mean value of $21.3 \%$ (Table 1). As a result, the consensus tree based on NJ and BI methods (Figure 2) formed three main clusters that discriminate Lignobrycon, Triportheus spp., and Astyanax fasciatus with high support values $(100 \%$ of bootstrap and 
TABLE 2: Interspecific genetic distances of COI sequences based on K2P model.

\begin{tabular}{lcccc}
\hline Species & Sample size $(n)$ & 1 & 2 & 3 \\
\hline (1) Lignobrycon myersi & 59 & - & & \\
(2) Triportheus guentheri & 4 & 0.174 & 0.246 & - \\
(3) Astyanax fasciatus & 3 & 0.220 & 0.082 & 0.227 \\
(4) Triportheus angulatus & 1 & 0.174 & 0.094 & 0.240 \\
(5) Triportheus nematurus & 4 & 0.183 & & 0.049 \\
\hline Mean & & 0.049 & & \\
\hline
\end{tabular}

TABLE 3: Intraspecific genetic distance $(D)$ and standard error (SE) of COI sequences based on K2P model.

\begin{tabular}{lccc}
\hline Species & Sample size $(n)$ & $D$ & SE \\
\hline Lignobrycon myersi & 59 & 0.004 & 0.001 \\
Triportheus guentheri & 4 & 0.001 & 0.001 \\
Astyanax fasciatus & 3 & 0.005 & 0.002 \\
Triportheus angulatus & 1 & $\mathrm{n} / \mathrm{c}$ & $\mathrm{n} / \mathrm{c}$ \\
Triportheus nematurus & 4 & 0.000 & 0.000 \\
\hline Mean & & 0.002 & \\
\hline
\end{tabular}

0.9-1 of a posteriori probability). The highest differentiation between Astyanax and the other genera (22 to 24\%) was expected because Lignobrycon and Triportheus have been recently removed from the family Characidae and placed into a distinct family (Triportheidae) according to phylogenetic analyses [16]. Indeed, L. myersi shares several synapomorphic traits with Triportheus, including an unusual sex chromosome system in Characiformes [17].

Moreover, five reciprocal monophyletic clusters were reliably recovered in the consensus tree (Figure 2), corresponding to the nominal species. Similarly, both species delimitation algorithms (ABGD and bPTP) indicated the presence of five species in the dataset (Figure 2). Indeed, the values of interspecific distance ranged from 4.9 to $24.6 \%$ (Table 2) while the intraspecific divergence varied from 0 ( $T$. nematurus) to $0.5 \%$ (A. fasciatus), with mean values of $0.2 \%$ (Table 3).

According to some authors [34], the minimum divergence values in COI sequences among the species should be, at least, 10 times higher than intraspecific variation to proper species identification. In this study, the genetic differences among species were, on average, 24.5 times higher than within species, characterizing the barcode gap. This result corroborates the efficiency of COI sequences in discriminating fish species $[15,19]$ with applications for taxonomy and forensic analyses as a reliable method of DNA authentication $[35,36]$ inasmuch as L. myersi was clearly distinguished from closely related species (Triportheus spp.) and from other species (A. fasciatus) commonly commercialized in regional markets along with $L$. myersi and other small characins under the same denomination ("piabas").

It should be pointed out that even though degraded DNA samples were obtained from most of frozen and saltpreserved specimens, the sequencing results were invariably congruent in L. myersi, yielding high-quality COI sequences
TABLE 4: Interpopulation genetic distance in COI sequences of Lignobrycon myersi based on K2P model.

\begin{tabular}{lccc}
\hline Population & Sample size & 1 & 2 \\
\hline (1) Almada River & 14 & - & \\
(2) Contas River & 41 & 0.005 & - \\
(3) Cachoeira River & 4 & 0.013 & 0.013 \\
\hline
\end{tabular}

from small tissue samples. Therefore, DNA barcoding has proved to be advantageous to the traceability of commercial fish products [35]. Taking into account that molecular identification of species using COI is fast and reliable, this genetic marker can be used to identify specimens of $L$. myersi in markets or food products. Indeed, COI sequences were informative to species identification even when closely related species were analyzed, like Triportheus (Figure 2).

In addition, the COI analysis allowed differentiating the population of L. myersi from Cachoeira River (bootstrap $=99.9 \%$; a posteriori probability $=0.9$ ) (Figure 2$)$, since this group presented a genetic distance of $1.3 \%$ in relation to samples from both Contas and Almada River (Table 4). Likewise, the haplotype network showed that the specimens from Cachoeira River are more genetically divergent, being separated from the other populations by six mutations (Figure 3). In fact, several DNA barcode studies in Neotropical ichthyofauna have detected high genetic divergence $(>2 \%)$ within a single putative taxonomic entity $[19,37,38]$. In these cases, the authors are unanimous in stating that cryptic species not formerly detected by traditional taxonomy should be present.

Indeed, the genetic divergence of L. myersi from Cachoeira River, although below the $2 \%$ threshold used in fish barcoding and without differentiation by ABGD and bPTP algorithms (Table 4; Figure 2), suggests that this population is structured. From a conservation viewpoint, this result implies that the specimens from Cachoeira River should be managed as a unique and endangered stock, particularly because of the intensified deforestation of marginal areas and pollution of this basin [39]. From a biogeographic perspective, this result contradicts the putative similarity between Almada and Cachoeira River basins based on fauna composition, geographic distance, and chromosomal data [40, 41]. Otherwise, the evolution of coastal hydrographic basins in Bahia seems to be more complex, probably alternating periods of connectivity and isolation such as headwater capture, as demonstrated in other reports [41, 42]. 
TABLE 5: Haplotype $(h)$ and nucleotide $(\pi)$ diversity in COI sequences within populations of Lignobrycon myersi.

\begin{tabular}{lccc}
\hline Population & Sample size & $h$ & $\pi$ \\
\hline Almada River & 14 & 0.396 & 0.002 \\
Contas River & 41 & 0.602 & 0.001 \\
Cachoeira River & 4 & 0.000 & 0.000 \\
\hline Total & 59 & 0.774 & 0.004 \\
\hline
\end{tabular}



Contas River

Almada River

Cachoeira River

FIGURE 3: Haplotype network based on COI sequences from the populations of L. myersi (Contas, Almada, and Cachoeira River basins). Each color represents a river basin and the circle size is equivalent to the number of individuals (shown inside the circles) sharing the same haplotype. The values on each line indicate the number of mutations.

Moreover, the levels of haplotype diversity $(h)$ were also differentiated among populations, ranging from 0 (a single haplotype) in Cachoeira River to 0.60 in Contas River samples (Table 5). Nonetheless, this variation might be biased by sample size, once the population of Cachoeira River was represented by four specimens while 41 individuals were obtained from Contas River. On the other hand, the population from Almada River, though composed of 14 analyzed specimens, presented the highest nucleotide divergence $(\pi=$ 0.002 ) (Table 5). In fact, this population is apparently larger and located on less impacted areas when compared to those from Cachoeira and Contas Rivers based on several field trips along the range of $L$. myersi over the last four years.

According to this observation, the population from Almada River seems to represent a suitable stock to genetic management of L. myersi with views to restoration or translocation of individuals, particularly in relation to Contas River, which probably corresponds to the most depleted population of $L$. myersi considering the illegal fishing and other human impacts such as introduction of exotic carnivore species, water contamination, and construction of dams [3].

\section{Conclusions}

We conclude that COI sequences are highly informative to the forensic genetics in the illegal trading of L. myersi, ensuring the detection of frauds or mislabeling of fisheries products even when morphological identification is impracticable.

This molecular approach is important for monitoring more precisely the impacts of overexploitation and genetic management of threatened fish species in northeastern Brazil and for supporting the application of law penalties against illegal fisheries. Nonetheless, this strategy should be accompanied by environmental education policies to awake the population about the regional biodiversity and reduce the demanding for the commercialization of L. myersi.

\section{Ethical Approval}

The experiments were approved by the Committee of Ethics in Experimentation in Animals by UESB (CEUA/UESB 32/2013).

\section{Competing Interests}

The authors declare that they have no competing interests.

\section{Acknowledgments}

The authors are grateful to Programa de Formação de Recursos Humanos da Petrobras (PRH-PB 211) and FAPESB (PNE0019/2011 and RED0009/2013) for the financial support, ICMBio for the authorization in collecting specimens (Licenses 26752-1 and 33398-1), and Dr. André Teixeira da Silva for his assistance during field trips.

\section{References}

[1] P. Camelier and A. M. Zanata, "Biogeography of freshwater fishes from the Northeastern Mata Atlântica freshwater ecoregion: distribution, Endemism, and area relationships," Neotropical Ichthyology, vol. 12, no. 4, pp. 683-698, 2014.

[2] C. Nogueira, P. A. Buckup, N. A. Menezes et al., "Restrictedrange fishes and the conservation of Brazilian freshwaters," PLoS ONE, vol. 5, no. 6, Article ID el1390, 2010.

[3] R. M. C. Castro and R. Jucá-Chagas, "Lignobrycon myersi (Miranda-Ribeiro, 1956)," in Livro Vermelho da Fauna Brasileira Ameaçada de Extinção, Ministério do Meio Ambiente, Ed., vol. 2, pp. 75-77, Ministério do Meio Ambiente, Brasília, Brasil, 1956.

[4] R. M. C. Castro and R. P. Vari, "Moojenichthys Miranda-Ribeiro (Pisces: Ostariophysi: Characidae), a phylogenetic reappraisal and redescription," Proceedings of the Biological Society of Washington, vol. 103, pp. 525-542, 1990.

[5] A. B. M. Machado, C. S. Martins, and G. M. Drummond, Lista da Fauna Brasileira Ameaçada de Extinção: Incluindo as Espécies Quase Ameaçadas e Deficientes em Dados, Fundação Biodiversitas, Belo Horizonte, Brazil, 2005.

[6] Ministério do Meio Ambiente, Plano Nacional de Recursos Hídricos, Ministério do Meio Ambiente, Secretaria de Recursos Hídricos (MMA), Brasília, Brazil, 2006.

[7] CEPENE-Centro de Pesquisa e Gestão de Recursos Pesqueiros do Litoral Nordeste, Boletim Estatístico da Pesca marítima 
e Estuarina do Nordeste do Brasil-IBAMA, CEPENE, PE, Tamandaré, Brazil, 2004.

[8] M. Woolfe and S. Primrose, "Food forensics: using DNA technology to combat misdescription and fraud," Trends in Biotechnology, vol. 22, no. 5, pp. 222-226, 2004.

[9] R. Ogden, "Unlocking the potential of genomic technologies for wildlife forensics," Molecular Ecology Resources, vol. 11, no. 1, supplement, pp. 109-116, 2011.

[10] C. A. M. Palmeira, L. F. D. S. Rodrigues-Filho, J. B. D. L. Sales, M. Vallinoto, H. Schneider, and I. Sampaio, "Commercialization of a critically endangered species (largetooth sawfish, Pristis perotteti) in fish markets of northern Brazil: authenticity by DNA analysis," Food Control, vol. 34, no. 1, pp. 249-252, 2013.

[11] M. A. de Brito, H. Schneider, I. Sampaio, and S. Santos, "DNA barcoding reveals high substitution rate and mislabeling in croaker fillets (Sciaenidae) marketed in Brazil: the case of 'pescada branca' (Cynoscion leiarchus and Plagioscion squamosissimus)," Food Research International, vol. 70, pp. 40-46, 2015.

[12] P. D. N. Hebert, S. Ratnasingham, and J. R. DeWaard, "Barcoding animal life: cytochrome $\mathrm{c}$ oxidase subunit 1 divergences among closely related species," Proceedings of the Royal Society B: Biological Sciences, vol. 270, no. 1, pp. S96-S99, 2003.

[13] R. D. Ward, T. S. Zemlak, B. H. Innes, P. R. Last, and P. D. N. Hebert, "DNA barcoding Australia’s fish species," Philosophical Transactions of the Royal Society B: Biological Sciences, vol. 360, no. 1462, pp. 1847-1857, 2005.

[14] J. Zhang and R. Hanner, "Molecular approach to the identification of fish in the South China Sea," PLoS ONE, vol. 7, no. 2, Article ID e30621, 2012.

[15] J. H. S. G. Brandão, J. A. Bitencourt, F. B. Santos et al., "DNA barcoding of coastal ichthyofauna from Bahia, northeastern Brazil, South Atlantic: high efficiency for systematics and identification of cryptic diversity," Biochemical Systematics and Ecology, vol. 65, pp. 214-224, 2016.

[16] C. Oliveira, G. S. Avelino, K. T. Abe et al., "Phylogenetic relationships within the speciose family Characidae (Teleostei: Ostariophysi: Characiformes) based on multilocus analysis and extensive ingroup sampling," BMC Evolutionary Biology, vol. 11, no. 1, article 275, 2011.

[17] A. S. Rodrigues, A. S. Medrado, D. Diniz, C. Oliveira, and P. R. A. M. Affonso, "ZZ/ZW sex chromosome system in the endangered fish Lignobrycon myersi Miranda-Ribeiro, 1956 (Teleostei, Characiformes, Triportheidae)," Comparative Cytogenetics, vol. 10, no. 2, pp. 245-254, 2016.

[18] D. C. De Carvalho, D. A. A. Oliveira, P. S. Pompeu, C. G. Leal, C. Oliveira, and R. Hanner, "Deep barcode divergence in Brazilian freshwater fishes: the case of the São Francisco River basin," Mitochondrial DNA, vol. 22, no. 1, pp. 80-86, 2011.

[19] L. H. G. Pereira, R. Hanner, F. Foresti, and C. Oliveira, "Can DNA barcoding accurately discriminate megadiverse Neotropical freshwater fish fauna?" BMC Genetics, vol. 14, article 20, 2013.

[20] A. Ardura, I. G. Pola, I. Ginuino, V. Gomes, and E. GarciaVazquez, "Application of barcoding to Amazonian commercial fish labelling," Food Research International, vol. 43, no. 5, pp. 1549-1552, 2010.

[21] N. V. Ivanova, T. S. Zemlak, R. H. Hanner, and P. D. N. Hebert, "Universal primer cocktails for fish DNA barcoding," Molecular Ecology Notes, vol. 7, no. 4, pp. 544-548, 2007.

[22] T. A. Hall, "BioEdit: a user-friendly biological sequence alignment editor and analysis program for Windows 95/98/NT," Nucleic Acids Symposium Series, vol. 41, pp. 95-98, 1999.
[23] J. D. Thompson, D. G. Higgins, and T. J. Gibson, "CLUSTAL $\mathrm{W}$ : improving the sensitivity of progressive multiple sequence alignment through sequence weighting, position-specific gap penalties and weight matrix choice," Nucleic Acids Research, vol. 22, no. 22, pp. 4673-4680, 1994.

[24] S. F. Altschul, T. L. Madden, A. A. Schäffer et al., "Gapped BLAST and PSI-BLAST: a new generation of protein database search programs," Nucleic Acids Research, vol. 25, no. 17, pp. 3389-3402, 1997.

[25] N. Saitou and M. Nei, "The neighbor-joining method: a new method for reconstructing phylogenetic trees," Molecular Biology and Evolution, vol. 4, no. 4, pp. 406-425, 1987.

[26] M. Kimura, "A simple method for estimating evolutionary rates of base substitutions through comparative studies of nucleotide sequences," Journal of Molecular Evolution, vol. 16, no. 2, pp. 111$120,1980$.

[27] K. Tamura, D. Peterson, N. Peterson, G. Stecher, M. Nei, and S. Kumar, "MEGA5: molecular evolutionary genetics analysis using maximum likelihood, evolutionary distance, and maximum parsimony methods," Molecular Biology and Evolution, vol. 28, no. 10, pp. 2731-2739, 2011.

[28] J. F. Felsenstein, "Confidence limits on phylogenies: an approach using the bootstrap," Evolution, vol. 39, no. 4, pp. 783-791, 1985.

[29] J. P. Huelsenbeck and F. Ronquist, "MrBayes: Bayesian inference of phylogenetic trees," Bioinformatics, vol. 17, no. 8, pp. 754-755, 2001.

[30] D. Darriba, G. L. Taboada, R. Doallo, and D. Posada, "JModelTest 2: more models, new heuristics and parallel computing," Nature Methods, vol. 9, no. 8, p. 772, 2012.

[31] J. Zhang, P. Kapli, P. Pavlidis, and A. Stamatakis, "A general species delimitation method with applications to phylogenetic placements," Bioinformatics, vol. 29, no. 22, pp. 2869-2876, 2013.

[32] J. C. Barrett, B. Fry, J. Maller, and M. J. Daly, "Haploview: analysis and visualization of LD and haplotype maps," Bioinformatics, vol. 21, no. 2, pp. 263-265, 2005.

[33] J. Rozas, P. Librado, J. C. Sánchez-Delbarrio, X. Messeguer, and R. Rozas, "DnaSP, DNA Sequence Polymorphism version 5.10. Universitat de Barcelona," 2010, http://www.ub.edu/dnasp/.

[34] P. D. N. Hebert, E. H. Penton, J. M. Burns, D. H. Janzen, and W. Hallwachs, "Ten species in one: DNA barcoding reveals cryptic species in the neotropical skipper butterfly Astraptes fulgerator," Proceedings of the National Academy of Sciences of the United States of America, vol. 101, no. 41, pp. 14812-14817, 2004.

[35] R. Ogden, "Fisheries forensics: the use of DNA tools for improving compliance, traceability and enforcement in the fishing industry," Fish and Fisheries, vol. 9, no. 4, pp. 462-472, 2008.

[36] L. Frézal and R. Leblois, "Four years of DNA barcoding: current advances and prospects," Infection, Genetics and Evolution, vol. 8, no. 5, pp. 727-736, 2008.

[37] D. C. Benzaquem, C. Oliveira, J. S. Batista, J. Zuanon, and J. I. R. Porto, "DNA barcoding in pencilfishes (Lebiasinidae: Nannostomus) reveals cryptic diversity across the Brazilian Amazon," PLoS ONE, vol. 10, no. 2, article e0112217, 2015.

[38] L. C. Gomes, T. C. Pessali, N. G. Sales, P. S. Pompeu, and D. C. Carvalho, "Integrative taxonomy detects cryptic and overlooked fish species in a Neotropical river basin," Genetica, vol. 143, no. 5, pp. 581-588, 2015.

[39] M. Cetra, L. M. Sarmento-Soares, and R. F. Martins-Pinheiro, "Peixes de riachos e novas Unidades de Conservação no sul da Bahia," Pan-American Journal of Aquatic Sciences, vol. 5, pp. 1121, 2010. 
[40] A. M. Zanata and P. Camelier, "Astyanax vermilion and Astyanax burgerai: new characid fishes (Ostariophysi: Characiformes) from Northeastern Bahia, Brazil," Neotropical Ichthyology, vol. 7, no. 2, pp. 175-184, 2009.

[41] A. S. Medrado, P. R. A. M. Affonso, P. L. S. Carneiro, M. R. Vicari, R. F. Artoni, and M. A. Costa, "Allopatric divergence in Astyanax aff. fasciatus Cuvier, 1819 (Characidae, Incertae sedis) inferred from DNA mapping and chromosomes," Zoologischer Anzeiger, vol. 257, pp. 119-129, 2015.

[42] I. A. Oliveira, L. A. Argolo, J. D. A. Bitencourt, D. Diniz, M. R. Vicari, and P. R. A. D. M. Affonso, "Cryptic chromosomal diversity in the complex 'Geophagus' brasiliensis (Perciformes, Cichlidae)," Zebrafish, vol. 13, no. 1, pp. 33-44, 2016. 

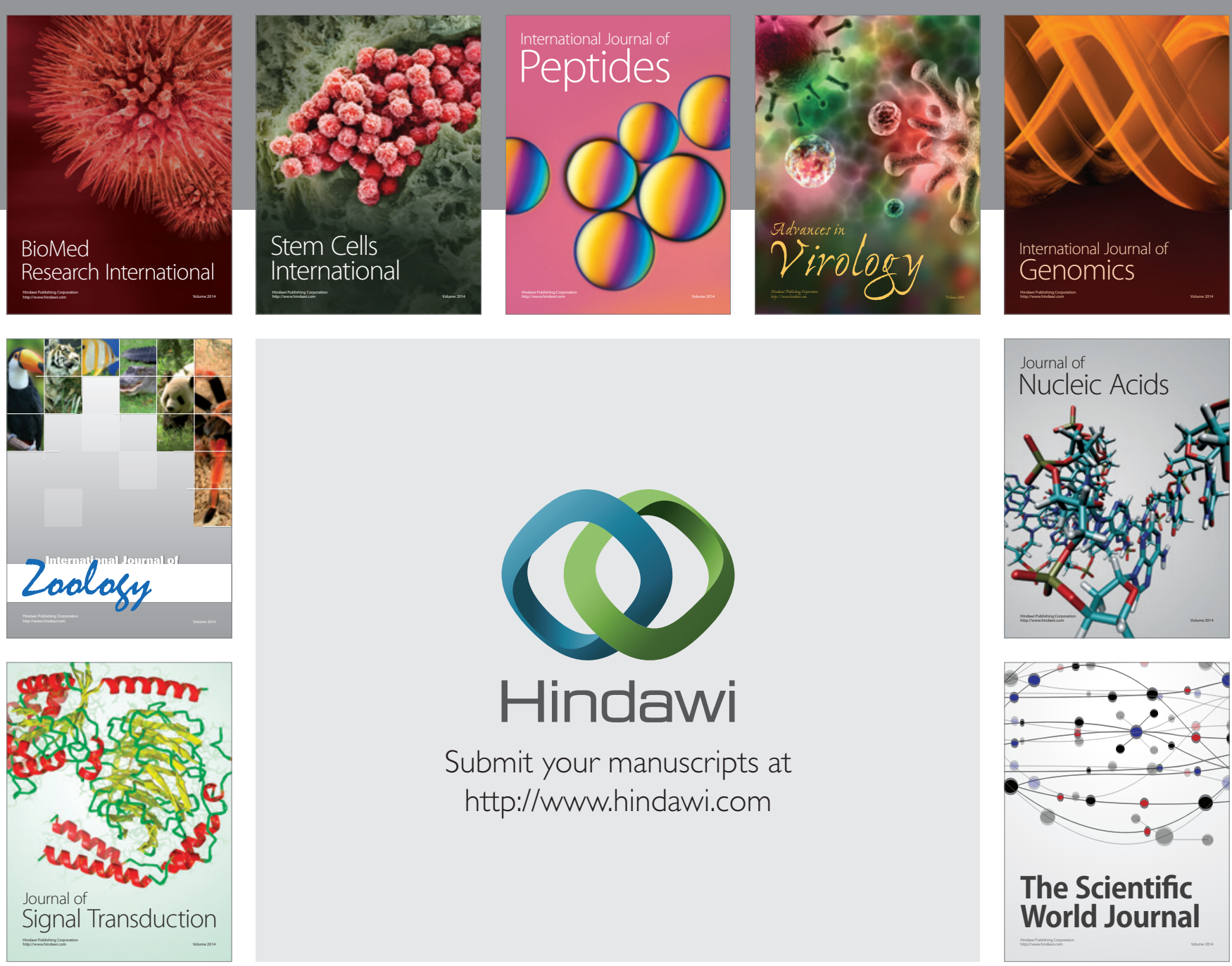

Submit your manuscripts at

http://www.hindawi.com
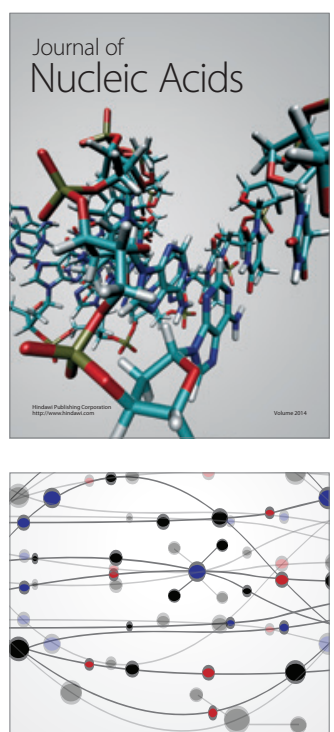

The Scientific World Journal
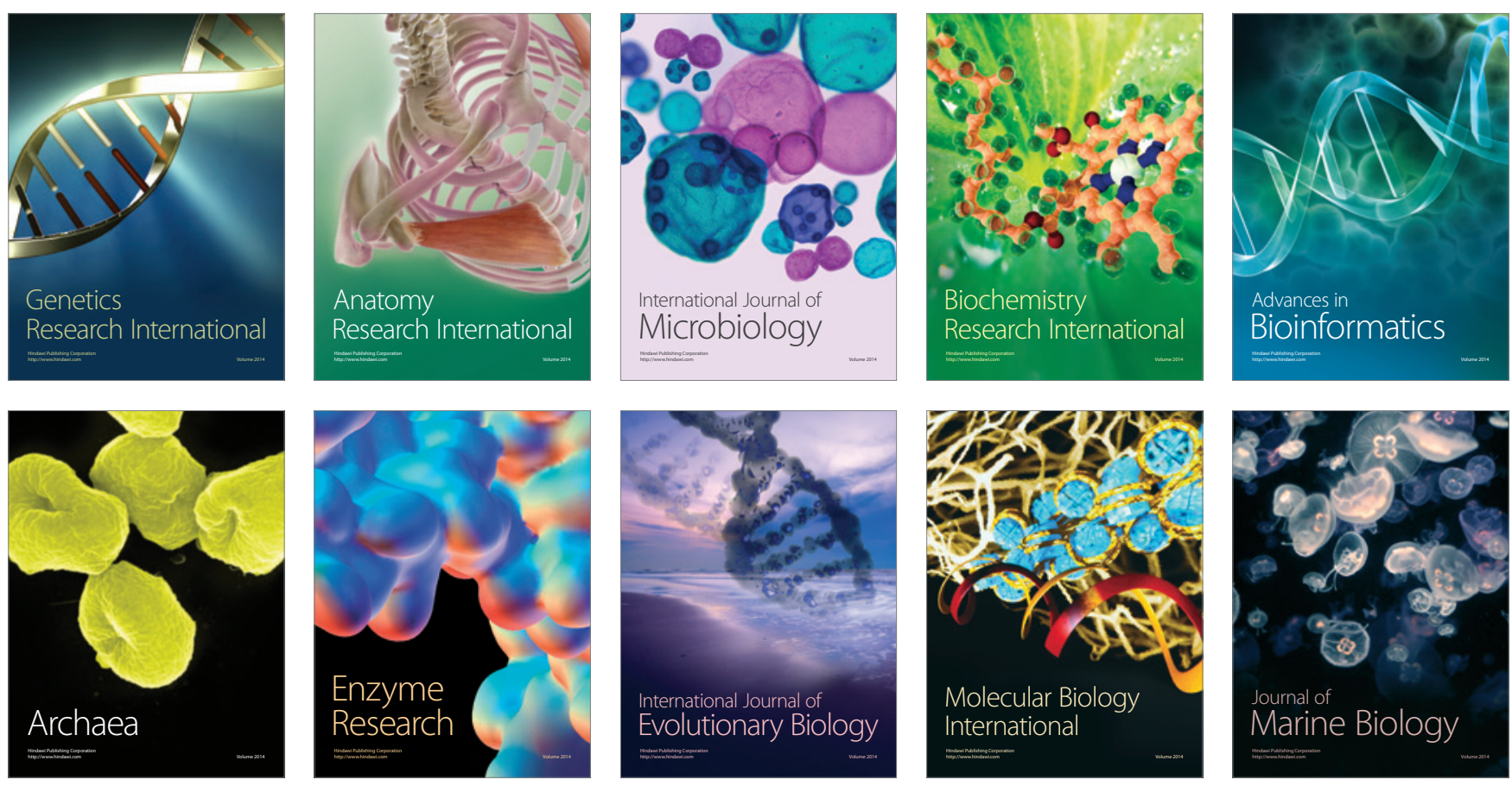